Judul jurnal yang di pakai untuk melengkapi makalah ini adalah

Analisis pemanfaatan ruang yang berwawasan lingkungan di kawasan pesisir Kota

Tegal 
MAKALAH

\title{
Geografi Ekonomi
}

Aktivitas Manusia Dalam Ruang

Yang Diampuh Oleh Roni Alim B.K, M.Pd.

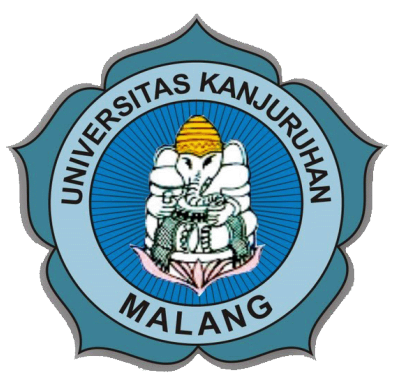

Oleh :

Kelompok II

Nama :

Theresia Ernita Hoar $\quad 160401050105$

Yunita Ginsta Kalin $\quad \mathbf{1 6 0 4 0 1 0 5 0 1 0 8}$

\author{
UNIVERSITAS KANJURUHAN MALANG \\ FAKULTAS ILMU PENDIDIKAN \\ PROGRAM STUDI PENDIDIKAN GEOGRAFI
}

2019 


\section{Kata Pengantar}

Puji Syukur Kehadirat Tuhan Yang Maha Esa Atas Segala Rahmat-Nya Sehingga Makalah Ini Dapat Tersusun Hingga Selesai . Tidak Lupa Kami Juga Mengucapkan Banyak Terimakasih Atas Bantuan Dari Pihak Yang Telah Berkontribusi Dengan Memberikan Sumbangan Baik Materi Maupun Pikirannya.

Dan Harapan Kami Semoga Makalah Ini Dapat Menambah Pengetahuan Dan Pengalaman Bagi Para Pembaca, Untuk Ke Depannya Dapat Memperbaiki Bentuk Maupun Menambah Isi Makalah Agar Menjadi Lebih Baik Lagi.

Karena Keterbatasan Pengetahuan Maupun Pengalaman Kami, Kami Yakin Masih Banyak Kekurangan Dalam Makalah Ini, Oleh Karena Itu Kami Sangat Mengharapkan Saran Dan Kritik Yang Membangun Dari Pembaca Demi Kesempurnaan Makalah Ini.

Malang, Februari 2019

Penulis 


\section{Daftar Isi}

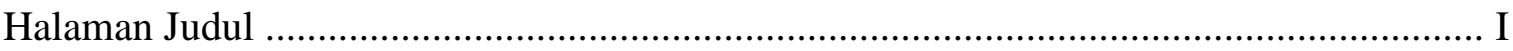

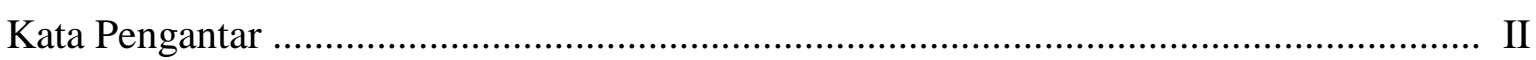

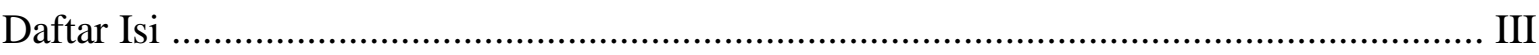

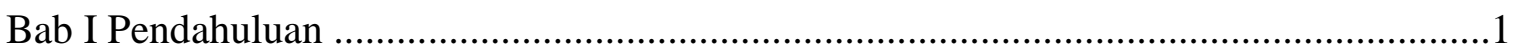

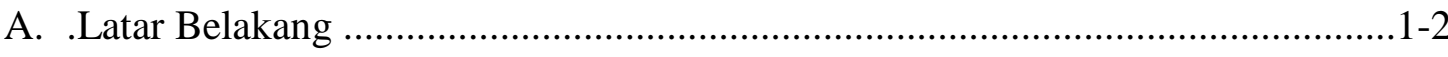
B. Rumusan Masalah ............................................................................................ 2

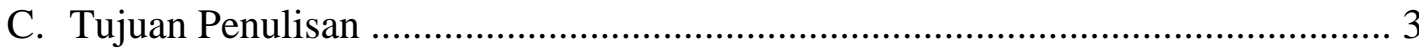

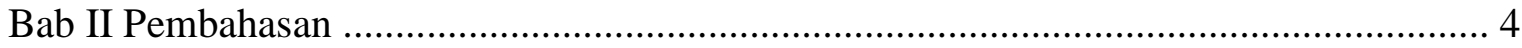
A. Pengertian Aktivitas Manusia Dalam Ruang 4
B. Jenis-jenis Aktivitas Manusia Dalam Ruang ..................................................... 4-9
C. Hubungan Aktivitas Manusia Dalam Ruang ..................................................... 9-10

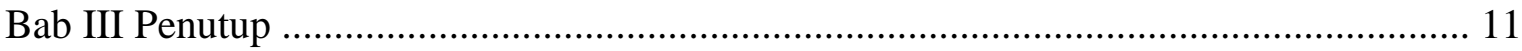
A. Kesimpulan $11-12$
B. Saran 12

Daftar Pustaka 


\section{BAB I \\ PENDAHULUAN}

\section{A. Latar Belakang}

Manusia dalam memenuhi kebutuhan hidupnya memerlukan sumberdaya alam, berupa tanah, air dan udara dan sumberdaya alam lain termasuk ke dalam sumberdaya alam yang terganti maupun yang tak terganti. Namun demikian harus disadari bahwa sumberdaya alam mempunyai keterbatasan di dalam banyak hal, yaitu keterbatasan tentang ketersediaan menurut kuantitas dan kualitasnya. Sumberdaya alam tertentu juga mempunyai keterbatasan menurut ruang dan waktu. Banyaknya penebangan kayu pada kawasan hutan produksi yang tidak sesuai atau tidak diketahui mempunyai izin, oleh sebab itu diperlukan pengelolaan sumberdaya alam yang baik dan bijaksana. Antara lingkungan dan manusia saling mempunyai kaitan yang erat. Keberadaan sumberdaya alam, air, tanah dan sumberdaya yang lain menentukan aktivitas manusia sehari-hari. Manusia tidak dapat hidup tanpa udara dan air. Sebaliknya ada pula aktivitas manusia yang sangat mempengaruhi keberadaan sumberdaya dan lingkungan di sekitarnya. Kerusakan sumberdaya Aaam banyak ditentukan oleh aktivitas manusia.

Pada awalnya mata pencaharian sangat tergantung potensi sekitar tempat tinggalnya, dan dalam perkembangan berikutnya manusia semakin cerdas dalam menangkap potensi yang ada, sehingga mata pencaharian tidak tergantung sepenuhnya terhadap alam. Dan tahap kehidupan masyarakatyang berkaitan dengan kegiatan ekonomi (Fundamental Occupation) sebagai berikut: berburu dan meramu, pastoral/menggembala, bertani, praindustri dan masyarakat pertanian moderen dan industri maju. Kegiatan tersebut semakin berkembang seiring perkembangan ilmu pengetahuan dan teknologi. Bahkan kegiatan ekonomi sekarang sudah mengalami perubahan orientasi, yaitu dari kegiatan ekonomi berbasis sumber daya alam berubah menjadi sumberdaya berbasis kreatifitas yang dikenal juga dengan istilah ekonomi kreatif.

\section{B. Rumusan Masalah}

Berdasarkan latar belakang masalah di atas, maka dapat di rumuskan beberapa masalah di antaranya adalah sebagai berikut :

1. Apa pengertian aktivitas manusia dalam ruang ?

2. Apa jenis-jenis aktivitas manusia dalam ruang?

3. Bagaimana hubungan aktivitas manusia dalam ruang?

\section{Tujuan Penulisan}

Adapun Tujuan Dari Penyusunan Makalah Ini Antara Lain Adalah :

1. Untuk mengetahui pengertian aktivitas manusia dalam ruang.

2. Untuk mengetahui jenis-jenis aktivitas manusia dalam ruang.

3. Untuk mengetahui hubungan kondisi geografis aktivitas manusia dalam ruang. 


\section{BAB II \\ PEMBAHASAN}

\section{A. Pengertian Aktivitas Manusia Dalam Ruang}

Aktivitas manusia adalah suatu perjalanan/suatu proses yang di lakukan manusia dalam mengelolah, memeperbaiki, dan menghasilkan. Sedangkan ruang yaitu tempat yang memberikan kita hidup karena di dalamnya terdapat unsur-unsur yang di perlukan untuk kehidupan manusia. Aktivitas ekonomi yang di bangun manusia menunjukkan bahwa manusia adalah mahluk sosial, yaitu kehidupan yang berlangsung tidak bisa melepaskan diri dari orang lain, khususnya dalam pemenuhan kebutuhan hidupnya. Satu kelompok masyarakat membutuhkan kelompok lain karena kehidupan yang berlangsung membutuhkan kerja sama untuk bersama-Sama memenuhi kebutuhan. masyarakat yang tinggal di pesisir membutuhkan sayuran dari pegunungan, sebaliknya masyarakat pegunungan membutuhkan ikan dari pesisir.

\section{B. Jenis-jenis Aktivitas Manusia Dalam Ruang}

\section{Pesisir}

Pesisir merupakan salah satu kawasan yang memiliki kekayaan sumber daya alam yang beragam dari lautan. Kawasan pesisir selain berfungsi sebagai penyedia sunber daya alam juga memiliki fungsi sebagai kawasan industri, perikanan, parawisata, permukiman, pelabuhan, dan pembuangan limbah. Contohnya referensi jurnal yang dipakai seperti Analisis pemanfaatan ruang yang berwawasan lingkungan di kawasan pesisir Kota Tegal. Dimana kawasan pesisir Kota Tegal merupakan salah satu kawasan di Jawa Tengah yang memiliki kekayaan sumber daya alam yang beragam dari lautan yang berfungsi sebagai penyedia sumber daya alam, sebagai kawasan industri, perikanan, parawisata, pelabuhan, dan tempat pembuangan limbah.

Secara umum sumber daya kelautan/laut yang berada di wilayah pesisir dan lautan dapat di bagi atas empat kelompok, yaitu sumber daya dapat pulih (Renewable Resources), sumber daya tidak dapat pulih (Non-Reneweble Resources), energi kelautan, dan jasa-jasa lingkungan kelautan (Environmental Services). Sumber daya dapat pulih (di perbaharui),potensi sumber daya dapat pulih terdiri dari sumberdaya perikanan tangkap, budidaya pantai (tambak), budidaya Laut, dan bioteknologi kelautan. Sumberdaya tidak dapat pulih (tidak di perbaharui). Sumber daya kelautan/laut yang tidak dapat di perbaharui yaitu: minyak bumi lepas pantai, dan tambang logam lepas pantai. Energi kelautan merupakan energi konvensional dan termasuk sumber daya kelautan non hayati yang dapat di perbaharui yang memiliki potensi untuk di kembangkan di kawasan Pesisir dan lautan.

$\Rightarrow$ Permasalahan yang di hadapi wilayah pesisir :

a. Kerusakan fisik habitat ekosistem pesisir

Kerusakan fisik habitat ekosistem wilayah pesisir di Indonesia umumnya terjadi pada ekosistem mangrove, terumbu karang dan rumput laut. Seperti terumbu karang di Indonesia yang masih berada dalam kondisi sangat baik hanya 6,20\%, kondisi rusak 41,78\%, kondisi 
sedang 28,30\%, dan kondisi baik 23,72 \% (Moosa Et.Al. 1996). Kerusakan terumbu karang umumnya di sebabkan oleh kegiatan-kegiatan perikanan yang bersifat destruktif seperti penggunaan bahan peledak dan beracun, penambangan karang, reklamasi pantai, pariwisata, dan sedimentasi akibat erosi dari lahan atas.

b. Over-eksploitasi sumber daya hayati laut.

Meskipun secara agregat (Nasional) sumberdaya perikanan laut di Indonesia baru dimanfaatkan sekitar 58,5 \% dari total potensi lestarinya, namun di beberapa kawasan perairan, beberapa stok sumber daya perikanan telah mengalami kondisi tangkap lebih (Overfishing) seperti di perairan selat Malaka (112,38 \%), laut Jawa $(88,98, \%)$, dan selat Makasar serta laut flores $(66,70 \%)$.

\section{c. Pencemaran.}

Tingkat pencemaran di beberapa kawasan pesisir dan lautan di Indonesia pada saat ini telah berada pada kondisi yang sangat memprihatinkan. kawasan yang termasuk dalam katagori dengan tingkat pencemaran tinggi adalah propinsi Jawa Barat, Jawa Timur, DKI Jakarta, Jawa Tengah, Sumatera Utara, Sumatera Selatan, Kalimantan Timur, Riau, Lampung, dan Sulawesi Selatan. Kawasan yang termasuk kategori tingkat pencemaran rendah .

$\Rightarrow$ Pengelolaan ruang wilayah pesisir dan lautan seiring dengan pelaksanaan otonomi daerah (Rokhimin Dahuri) adalah Irian Jaya,Sulawesi Tengah, Sulawesi Tenggara, Bengkulu, dan Nusa Tenggara Timur. Sumber utama pencemaran pesisir dan lautan terdiri dari tiga jenis kegiatan di darat, yaitu kegiatan industri, kegiatan rumah tangga, Dan kegiatan pertanian. Sedangkan sumber pencemaran yang berasal dari berbagai kegiatan di laut meliputi perhubungan laut dan kapal pengangkut minyak, kegiatan pertambangan dan energi lepas pantai.

\section{d. Konflik pemanfaatan ruang}

Ketidak terpaduan berbagai kegiatan pemanfaatan ruang di wilayah pesisir dalam memanfaatkan sumber daya wilayah pesisir telah memicu konflik kepentingan sektor, swasta, dan masyarakat. Penyebab utamanya karena selama ini belum adanya aturan yang jelas baik dari segi hukum maupun substansi mengenai penataan ruang wilayah pesisir dan lautan. Kegiatan yang tidak terpadu itu selain kurang bersinergi juga sering saling mengganggu dan merugikan antar kepentingan, seperti kegiatan industri yang polutif dengan degiatan perikanan yang berdampingan. Permasalahan lain yang merupakan permasalahan klasik meliputi keterbatasan sumber daya pembangunan, rendahnya kualitas sumber daya manusia, kemiskinan masyarakat pesisir, kurangnya koordinasi antar pelaku pembangunan, dan lemahnya penegakan hukum.

Pentingnya pengelolaan wilayah pesisir pada hakekatnya terdapat beberapa alasan yang melatar belakangi pentingnya pengelolaan wilayah pesisir, yaitu :

1. Wilayah pesisir merupakan salah satu kawasan yang memiliki produktivitas hayati yang tinggi. Perairan (Coastal Waters) daerah tropis seperti Indonesia, mendapatkan masukan unsur hara (Nutrients) dari daratan melalui aliran sungai dan aliran air permukaan (Run Off) ketika hujan, serta siraman sinar matahari sepanjang tahun, sehingga memungkinkan proses fotosintesa terjadi sepanjang tahun

2. Wilayah pesisir memiliki potensi keindahan dan kenyamanan sebagai tempat rekreasi dan pariwisata. Selain itu karena adanya kemudahan transportasi dan distribusi barang dan jasa, sumber air pendingin bagi industri, dan tempat pembuangan limbah 
3. Pengelolaan ruang wilayah pesisir dan lautan seiring dengan pelaksanaan otonomi daerah lahan atas , terutama berupa bahan pencemar dan sedimen dari erosi tanah.

4. Wilayah pesisir biasanya merupakan sumber daya milik bersama (Common Property Resources), sehingga berlaku Rejim Open Access (siapa saja boleh memanfaatkan wilayah ini untuk berbagai kepentingan). Pada Rejim Open Accessini, setiap pengguna Ingin Memanfaatkan Sumberdaya Pesisir Semaksimal Mungkin Sehingga Sulit Dilakukan pengendalian, dan sering kali terjadi kehancuran ekosistem sebagai akibat tragedi bersama (Tragedy Of The Common). Keadaan demikian dapat menjadi potensi konflik. dengan karakterstik wilayah pesisir.

$\Rightarrow$ Pemanfaatan sumberdaya pesisir secara optimal dan berkesinambungan hanya dapat terwujud jika pengelolaannya di lakukan secara terpadu, menerapkan prinsip-prinsip pembangunan berkelanjutan (Sustainable Develop-Ment), serta pendekatan pembangunan secara hati-hati (Precautionary Approach)

\section{Pegunungan}

Pegunungan merupakan sebuah dataran yang menjulang dari sekelilingnya. Pegunungan juga merupakan perbukitan yang memiliki ketinggian antara $500 \mathrm{~m}$ hingga $600 \mathrm{~m}$ dari permukaan air laut.

\section{$\Rightarrow$ Aktivitas penduduk di daerah pegunungan}

Kondisi iklim di pegunungan pada umumnya sedang hingga dingin. Hal ini sangat cocok untuk kegiatan-kegiatan, berikut ini:

a. Pertanian dan perkebunan, terutama untuk padi, sayuran, teh, kopi, buah-buahan, serta berbagai jenis bunga dan tanaman hias.

b. Peternakan, terutama sapi, hal ini dikarenakan ketersediaan rumput dan air yang pada umumnya cukup melimpah.

c. Sebagai tujuan wisata, karena pada umumnya, daerah pegunungan mempunyai pemandangan alam yang indah, seperti air terjun, danau, dan agrowisata.

d. Pada lereng-lereng pegunungan, biasanya pemanfaatannya terbatas untuk areal hutan lindung yang fungsinya telah dikembangkan lebih lanjut menjadi hutan produksi ataupun hutan wisata.

\section{Dataran Rendah}

Dataran rendah merupakan daerah datar yang memiliki ketinggian hampir sama, yaitu 0-200 m di atas permukaan laut. Datan rendah adalah hamparan luas tanah dengan tingkat ketinggian yang di ukur dari permukaan laut adalah relatif rendah (sampai dengan $200 \mathrm{~m} \mathrm{dpl}$ ). Pada umumnya daearah dataran rendah dijadikan sebagai tempat permukiman penduduk, mendirikan pabrik, membangun gedung, dan membangun jalan raya.

Lokasi yang datar, menyebabkan pengembangan daerah dapat dilakukan seluas mungkin. Pembangunan jalan raya dan jalan tol serta kelengkapan saran transportasi ini telah mendorong daerah dataran rendah menjadi pusat ekonomi penduduk. Kemudahan transportasi dan banyaknya pusat-pusat kegiatan di daerah dataran rendah menarik penduduk untuk menetap disana. Oleh karena, itu penduduknya semakin bertambah dan kebutuhan tempat tinggal serta tempat usaha juga meningkat. 
Kemudahan transportasi dan banyaknya pusat-pusat kegiatan di daerah dataran rendah menarik penduduk untuk menetap disana. Oleh karena, itu penduduknya semakin bertambah dan kebutuhan tempat tinggal serta tempat usaha juga meningkat. Lahan-lahan seperti sawah dan hutan sebagai penyangga keseimbangan alam semakin berkurang digantikan oleh tumbuhnya bangunan bertingkat.Hal ini banyak menimbulkan permasalahan, seperti daerah resapan air berkurang yang mengakibatkan banjir pada saat musim hujan dan kekeringan pada saat musim kemarau.

\section{$\Rightarrow$ Aktivitas penduduk di dataran Rendah}

a. Topografinya yang relatif datar membuat kawasan ini layak untuk semua bentuk penggunaan lahan, baik itu untuk pertanian, permukiman, industri, ataupun bentukbentuk penggunaan lahan yang lain.

b. Sebagai lahan pertanian, daerah dataran rendah pada umumnya subur karena proses sedimentasi. Jenis tanaman yang cocok, antara lain, padi, palawija, kacangkacangan, dan buah-buahan.

c. Sebagai lokasi permukiman, daerah ini dapat cepat mengalami perkembangan ke segala arah.

d. Dari segi pembangunan sarana dan prasarana sosial, daerah dataran rendah lebih mudah diusahakan. Hal ini dikarenakan reliefnya datar sehingga sedikit ditemui barier alam serta kondisi tanah yang cukup stabil.

e. Sehubungan dengan ketersediaan sarana dan prasarana, dataran rendah juga sangat cocok digunakan sebagai kawasan industri.

\section{Hubungan Aktivitas Manusia Dalam Ruang}

Pola kehidupan manusia cenderung dipengaruhi oleh kondisi fisik lingkungan setempat, tidak terkecuali dengan kehidupan sosial ekonominya.Dalam memenuhi kebutuhan hidupnya, pemanfaatan lahan oleh manusia harus disesuaikan dengan kondisi fisik lainnya, antara lain jenis tanah, cuaca, ketersediaan air, kemiringan lereng, ataupun dengan kondisi curah hujannya.

Secara umum, pemusatan manusia atau penduduk menempati wilayah yang mempunyai ciri fisik ideal, antara lain, topografinya datar atau landai, mudah memperoleh air, tanah, kondisi udara sejuk, dan kondisi tanah yang subur.Akan tetapi, kondisi ideal ini tidak tersebar merata di permukaan bumi ini. Oleh karena itu, manusia dituntut mampu beradaptasi dan mengembangkan kemampuan dirinya agar dapat mengurangi pengaruh lingkungan yang kurang menguntungkan. Berdasarkan pengaruh kondisi lingkungan fisiknya, aktivitas sosial ekonomi manusia dapat dibedakan menjadi tiga, yaitu aktivitas manusia di daerah pesisir, pegunungan dan dataran rendah.

Kondisi alamiah dan manusia pada dasarnya memiliki hubungan timbal balik. Hubungan inilah yang mengakibatkan manusia memiliki karakteristik berbeda-beda disetiap wilayahnya. Aktivitas penduduk di suatu daerah sangat dipengaruhi oleh kondisi geografis terutama kondisi fisiknya. Kondisi daratan dengan segala kenampakannya merupakan tempat tinggal manusia dengan segala aktivitasnya. Mulai dari ketinggian paling rendah yang terletak di pantai sampai daerah puncak gunung. 
Aktivitas penduduk yang terkait pada kondisi alam dapat diketahui dari corak kehidupan penduduknya, yakni:

1. Corak kehidupan di daerah pantai. Penduduk umumnya bekerja sebagai nelayan, penjual jasa wisata, sektor perikanan dan perkebunan kelapa.

2. Corak kehidupan di daerah dataran rendah. Penduduk biasanya bekerja pada sektor pertanian, ladang dan bentuk pertanian lain. Selain itu sektor-sektor lain biasanya lebih cepat berkembang seperti transportasi, industri, dan perdagangan.

3. Corak kehidupan daerah pegunungan. Penduduk di daerah ini umumnya bekerja dalam sektor pertanian, ladang dan buruh perkebunan 


\section{BAB III \\ PENUTUP}

\section{A. Kesimpulan}

Manusia dalam memenuhi kebutuhan hidupnya memerlukan sumber daya alam, berupa tanah, air dan udara dan sumber daya alam lain termasuk ke dalam sumber daya alam yang terganti maupun yang tak terganti. Namun demikian harus disadari bahwa sumber daya alam mempunyai keterbatasan di dalam banyak hal, yaitu keterbatasan tentang ketersediaan menurut kuantitas dan kualitasnya.

Pola kehidupan manusia cenderung dipengaruhi oleh kondisi fisik lingkungan setempat, tidak terkecuali dengan kehidupan sosial ekonominya.Dalam memenuhi kebutuhan hidupnya, pemanfaatan lahan oleh manusia harus disesuaikan dengan kondisi fisik lainnya, antara lain jenis tanah, cuaca, ketersediaan air, kemiringan lereng, ataupun dengan kondisi curah hujannya. Kondisi alamiah dan manusia pada dasarnya memiliki hubungan timbal balik. Hubungan inilah yang mengakibatkan manusia memiliki karakteristik berbeda-beda disetiap wilayahnya. Kondisi daratan dengan segala kenampakannya merupakan tempat tinggal manusia dengan segala aktivitasnya.

$\Rightarrow$ Pesisir

Pesisir merupakan salah satu kawasan yang memiliki kekayaan sumber daya alam yang beragam dari lautan. Kawasan pesisir selain berfungsi sebagai penyedia sunber daya alam juga memiliki fungsi sebagai kawasan industri, perikanan, parawisata, permukiman, pelabuhan, dan pembuangan limbah.

$\Rightarrow$ Pegunungan

Pegunungan merupakan sebuah dataran yang menjulang dari sekelilingnya. Pegunungan juga merupakan perbukitan yang memiliki ketinggian antara $500 \mathrm{~m}$ hingga $600 \mathrm{~m}$ dari permukaan air laut.

$\Rightarrow$ Dataran Rendah

Dataran rendah merupakan daerah datar yang memiliki ketinggian hampir sama, yaitu 0-200 m di atas permukaan laut. Datan rendah adalah hamparan luas tanah dengan tingkat ketinggian yang di ukur dari permukaan laut adalah relatif rendah (sampai dengan $200 \mathrm{~m} \mathrm{dpl}$ ). Pada umumnya daearah dataran rendah dijadikan sebagai tempat permukiman penduduk, mendirikan pabrik, membangun gedung, dan membangun jalan raya.

\section{B. Saran}

Aktivitas manusia dalam ruang terdapat berbagai permasalahan yaitu baik di pesisir, pegunungan maupun di dataran rendah yang di sebabkan oleh manusia itu sendiri. Oleh karena itu di lakukan pemanfaatan sumberdaya pesisir, pegunungan maupun dataran rendah secara optimal dan berkesinambungan dengan menerapkan prinsip-prinsip pembangunan berkelanjutan (Sustainable Develop-Ment), serta pendekatan pembangunan secara hati-hati (Precautionary Approach). 


\section{DAFTAR PUSTAKA}

http://muhsholeh.blogspot.co.id/2010/03/materi-2-geo-sosial.html

Dahuri, Rokhmin et al. 2001. Pengelolaan Sumberdaya Wilayah Pesisir dan Lautan Secara Terpadu. PT Pradnya Paramita . Jakarta. 